\title{
BLOOD TRANSFUSION IN OBSTETRIC HAEMORRHAGE AND THEIR OUTCOME IN TERTIARY CARE HOSPITAL IN RURAL AREA
}

Vijaya Ganapathy1, Rani Vasantha Kumari Shunmugavelu²

${ }_{1}^{1}$ Professor, Department of Anaesthesiology, Government Theni Medical College, Theni, Tamilnadu.

${ }^{2}$ Assistant Professor, Department of Anaesthesiology, Government Theni Medical College, Theni, Tamilnadu.

\section{ABSTRACT}

\section{BACKGROUND}

Obstetric haemorrhage remains the main cause of maternal mortality and morbidity, even though advanced medical and surgical managements and blood transfusions are available. Haemorrhagic shock is a very serious complication. Obstetric haemorrhage occur either in antepartum, intrapartum or postpartum period. Here, our aim is to study the outcome of blood transfusion in obstetric haemorrhage patients.

Study Method- Retrospective observational study.

\section{MATERIALS AND METHODS}

In present study, 250 patients of obstetric haemorrhage who were in antepartum, intrapartum and postpartum period were included. Amount of various blood transfusion products used were noted. Patient's outcome like safe discharge, morbidity and mortality were noted.

\section{RESULTS}

1423 units of blood and blood components transfusion was done on 250 obstetric haemorrhage patients. Out of 250 patients 228 patients were discharged in stable condition, 4 patients were referred to higher centres for dialysis and 18 maternal mortality was noted.

\section{CONCLUSION}

The management of obstetric haemorrhage is a challenging task which needs a team work of improved obstetric care, anaesthesiologist support, timely interventions, availability of blood and blood products and intensive care unit.

\section{KEYWORDS}

Obstetric haemorrhage, maternal outcome, blood transfusion.

HOW TO CITE THIS ARTICLE: Ganapathy V, Shunmugavelu RVK. Blood transfusion in obstetric haemorrhage and their outcome in tertiary care hospital in rural area. J. Evolution Med. Dent. Sci. 2017;6(69):4934-4937, DOI: 10.14260/Jemds/2017/1070

\section{BACKGROUND}

Obstetric haemorrhage is the main cause of maternal morbidity and mortality. WHO data indicates haemorrhage accounts for $35 \%$ of maternal mortality. Antepartum, intrapartum and postpartum haemorrhage can be managed effectively by the management of obstetric cause of bleeding and blood transfusion.

The aim of the study was to determine the outcome of blood transfusion in obstetric haemorrhage patients.

\section{MATERIALS AND METHODS}

This study was conducted at the Department of Anaesthesia in Government Theni Medical College, Theni, from January 2013 - December 2016. It was a Retrospective Observational study. This study was conducted in patients who underwent surgery in emergency operation theatre. These patients were under antepartum, intrapartum and postpartum periods. Ectopic rupture and abortion in early pregnancy; abruption and placenta previa in late pregnancy; intrapartum and postpartum atonic $\mathrm{PPH}$, traumatic $\mathrm{PPH}$ and secondary $\mathrm{PPH}$.

Financial or Other, Competing Interest: None.

Submission 18-07-2017, Peer Review 17-08-2017,

Acceptance 23-08-2017, Published 28-08-2017.

Corresponding Author:

Dr. Rani Vasantha Kumari Shunmugavelu,

W/o. Dr. K. Paraman,

Anbu Clinic, Vellpar Koil Street,

Aundipatty, Theni District.

E-mail: drparamanrani62@gmail.com

DOI: $10.14260 /$ jemds $/ 2017 / 1070$

\section{RESULTS}

\begin{tabular}{|c|c|c|c|c|}
\hline Parameter & $\begin{array}{c}\text { Compensa } \\
\text { ted }\end{array}$ & Mild & Moderate & Severe \\
\hline $\begin{array}{c}\text { Blood loss } \\
\text { (mL) }\end{array}$ & 1000 & 1500 & $1500-2000$ & $\geq 2000$ \\
\hline $\begin{array}{c}\text { Heart Rate } \\
\text { (bpm) }\end{array}$ & 100 & $101-120$ & $121-140$ & $\geq 140$ \\
\hline $\begin{array}{c}\text { Blood } \\
\text { pressure } \\
\text { (mmHg) }\end{array}$ & Normal & $\begin{array}{c}\text { Orthostatic } \\
\text { hypotensio } \\
\mathrm{n}\end{array}$ & Marked fall & $\begin{array}{c}\text { Profound } \\
\text { fall }\end{array}$ \\
\hline $\begin{array}{c}\text { Capillary } \\
\text { refill }\end{array}$ & Normal & $\begin{array}{c}\text { May be } \\
\text { delayed }\end{array}$ & $\begin{array}{c}\text { Usually } \\
\text { delayed }\end{array}$ & $\begin{array}{c}\text { Always } \\
\text { delayed }\end{array}$ \\
\hline $\begin{array}{c}\text { Respiratory } \\
\text { Rate }\end{array}$ & Normal & $\begin{array}{c}\text { Mild } \\
\text { increase }\end{array}$ & $\begin{array}{c}\text { Moderate } \\
\text { tachypnoea }\end{array}$ & $\begin{array}{c}\text { Marked } \\
\text { tachypnoea }\end{array}$ \\
\hline $\begin{array}{c}\text { Urinary } \\
\text { output }\end{array}$ & $\geq 30$ & 20-30 & 5-20 & Anuria \\
\hline $\begin{array}{c}\text { Mental } \\
\text { status }\end{array}$ & $\begin{array}{c}\text { Normal } \\
\text { agitated }\end{array}$ & Agitated & Confused & $\begin{array}{c}\text { Lethargic/ } \\
\text { obtunded }\end{array}$ \\
\hline \multicolumn{2}{|c|}{ Table 1. Classification of Haemorrhagic Shock[1,2,3] } \\
\hline
\end{tabular}

Shock occurs when there is hypoperfusion of vital organs, which will vary depending on the volume and rate of blood loss. ${ }^{[4,5]}$ A defined volume of blood loss is difficult to measure due to physiological changes and comorbid conditions. The loss evaluated is usually underestimated up to $35 \% .[6,7]$ The initial resuscitation is with isotonic crystalloid solution. In emergency situations, 0 negative blood can be used. Investigation, diagnosis and definitive treatment either by 
medical or surgical intervention to arrest bleeding at the earliest is must. Many available guidelines for transfusion are mostly from developed countries; however, they can be used by developing countries keeping available resources in perspective. For maternal outcome, the mortality and morbidity were considered. All information was gathered and results were analysed.

\begin{tabular}{|c|c|c|c|}
\hline $\begin{array}{r}\text { Sl. } \\
\text { No. }\end{array}$ & Aetiology & Number of Patients & Percentage \\
\hline 1 & Abortion & 5 & $2 \%$ \\
\hline 2 & Ectopic pregnancy & 150 & $60 \%$ \\
\hline 3 & Abruptio placenta & 25 & $10 \%$ \\
\hline 4 & Placenta previa & 5 & $2 \%$ \\
\hline 5 & Rupture uterus & 5 & $2 \%$ \\
\hline 6 & Traumatic PPH & 15 & $6 \%$ \\
\hline 7 & Secondary PPH & 3 & $1.2 \%$ \\
\hline 8 & Atonic PPH & 42 & $14.8 \%$ \\
\hline
\end{tabular}

\section{Table 2. Distribution of Aetiology of Our Study Patients}

Table 2 shows even though ectopic pregnancy was high (60\%) in our study; the atonic PPH (14.8\%) was the commonest cause of severe obstetric haemorrhage in our emergency theatre, since out of 150 ectopic patients 100 patients were in compensated stage.

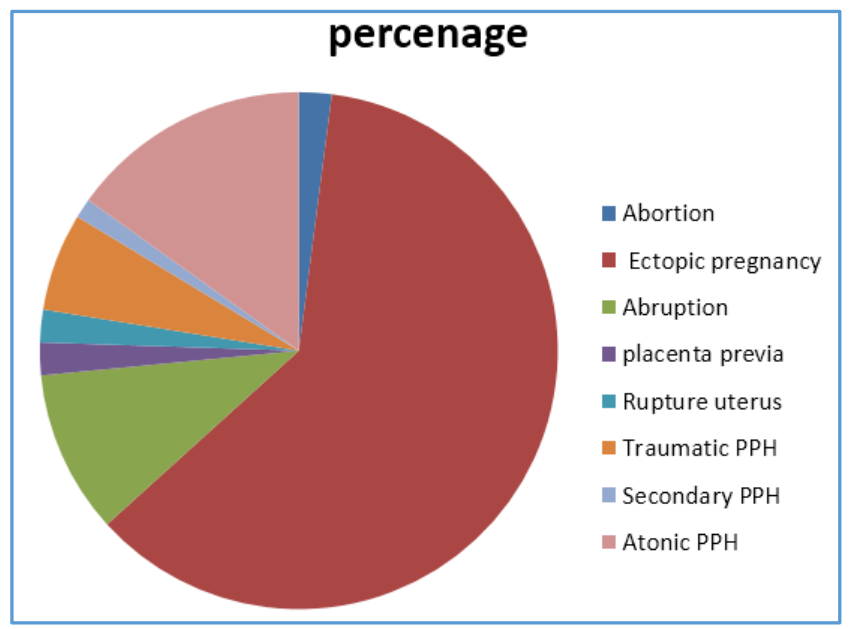

Graph 1. Distribution of Classification of Shock

Table 3 shows all the obstetric haemorrhage patients presenting in our emergency operation theatre, the severity of haemorrhagic shock was also high in atonic PPH patients.

\begin{tabular}{|c|c|c|c|c|c|}
\hline $\begin{array}{c}\text { Sl. } \\
\text { No. }\end{array}$ & Aetiology & $\begin{array}{c}\text { Compen- } \\
\text { sated }\end{array}$ & Mild & Moderate & Severe \\
\hline 1 & Abortion & & & 2 & 3 \\
\hline 2 & Ectopic & 100 & 30 & 15 & 5 \\
\hline 3 & Abruption & & 5 & 15 & 5 \\
\hline 4 & Placenta previa & & 3 & 2 & \\
\hline 5 & Rupture uterus & & & 3 & 2 \\
\hline 6 & Traumatic PPH & 5 & 5 & 5 & \\
\hline 7 & Secondary PPH & & & 2 & 1 \\
\hline 8 & Atonic PPH & & 5 & 22 & 15 \\
\hline \multicolumn{7}{|c|}{ Table 3. Distribution of Classification of Shock } \\
\hline
\end{tabular}

\begin{tabular}{|c|c|c|c|c|c|}
\hline Aetiology & $\begin{array}{c}\text { Whole } \\
\text { Blood }\end{array}$ & $\begin{array}{c}\text { Packed } \\
\text { Cell }\end{array}$ & FFP & Platelet & Total \\
\hline Abortion & 15 & 10 & 20 & 4 & 49 \\
\hline Ectopic & 170 & 200 & 120 & 5 & 495 \\
\hline Abruption & 50 & 70 & 105 & 6 & 231 \\
\hline Placenta previa & 10 & 15 & 8 & & 33 \\
\hline Rupture uterus & 15 & 14 & 16 & 3 & 48 \\
\hline Traumatic PPH & 20 & 25 & 30 & & 75 \\
\hline Secondary PPH & 10 & 10 & 15 & 2 & 37 \\
\hline Atonic PPH & 140 & 145 & 150 & 20 & 455 \\
\hline Total & $\mathbf{4 3 0}$ & $\mathbf{4 8 9}$ & $\mathbf{4 6 4}$ & $\mathbf{4 0}$ & $\mathbf{1 4 2 3}$ \\
\hline Table 4. Distribution of Usage of Blood Components \\
\hline
\end{tabular}

Table 4 shows the usage of blood components are high in Atonic PPH where we used WB, PC, FFP and Platelets. The number of Ectopic patients were high and most of them had single unit blood transfusion.

Table 5 shows out of 250 patients, 3 patients had mild allergic blood transfusion reaction which was managed by steroids. Four patients went for acute renal shutdown and they were referred for dialysis; 60 patients of moderate and severe haemorrhage were put on mechanical ventilation and extubated after 24 hours; 18 patients died. Out of 18 patients, 13 died of DIC. The commonest cause of our hospital mortality was DIC. Two patients died due to sepsis (septic abortion), 2 patients from renal failure and 1 patient from ARDS.

\begin{tabular}{|c|c|c|c|}
\hline $\begin{array}{l}\text { Sl. } \\
\text { No. }\end{array}$ & Maternal Outcome & $\begin{array}{c}\text { Number of } \\
\text { Patients } \\
(n=250)\end{array}$ & Percentage \\
\hline \multirow{4}{*}{1} & Morbidity & & \\
\hline & $\begin{array}{l}\text { 1. Mild acute blood } \\
\text { transfusion reaction }\end{array}$ & 3 & $1.2 \%$ \\
\hline & 2. $\mathrm{ARF}$ & 4 & $1.6 \%$ \\
\hline & 3. Mechanical ventilation & 60 & $24 \%$ \\
\hline \multirow{5}{*}{2} & Mortality & & $7.5 \%$ \\
\hline & 1. DIC & 13 & \\
\hline & 2. Sepsis & 2 & \\
\hline & 3. Renal failure & 2 & \\
\hline & 4. ARDS & 1 & \\
\hline \multirow{2}{*}{3} & Referral & & $1.6 \%$ \\
\hline & Acute renal shutdown & 4 & \\
\hline 4 & Discharged in good condition & 228 & $91 \%$ \\
\hline \multicolumn{4}{|c|}{ Table 5. Distribution of Maternal Outcome } \\
\hline
\end{tabular}

\section{DISCUSSION}

Management of obstetric haemorrhage is more challenging for anaesthesiologist. In pregnant woman, there is $50 \%$ physiological increase in intravascular volume (i.e. 4 - $6 \mathrm{~L}$ ). Therefore, the signs of haemorrhagic shock such as tachycardia, hypotension and a cold clammy skin were seen after a significant loss of blood. The extent of intravascular volume deficit is not correctly reflected by the vaginal bleeding.[8,4]

Standard definitions of postpartum haemorrhage, that is > $500 \mathrm{~mL}$ after vaginal delivery and $>1000 \mathrm{~mL}$ after caesarean section do not adequately reflect the clinical response of the patient. Definitions of massive haemorrhage vary and have limited value. It may arbitrarily be considered a situation where $1-1.5 \mathrm{~L}$ of blood volumes may need to be transfused acutely or in a 24 -h period where normal blood volume in the 
adult is taken as approximately $7 \%$ of ideal body weight. Other definitions include $50 \%$ blood volume loss within 3 -h or a rate of loss of $150 \mathrm{~mL} / \mathrm{min}$.

Haemorrhagic shock is caused by a reduction in the circulating blood volume. The decreased circulating volume leads to decrease in oxygen supply to cells, which leads to organ dysfunction. ${ }^{[4,6]}$ The human body tries to compensate for the blood loss. This mechanism aims to protect the vital organs (brain and heart) in an attempt to sustain life.

If unrecognised or left untreated, cell death due to hypoxic injury will follow. ${ }^{[6]}$ So oxygenation is very important. The outcome is dependent on three basic principles; 1 . Early adequate giving of supplemental oxygen, 2 . Arrest the bleeding and 3. Replacing the blood loss. ${ }^{[5,9]}$

Most protocols recommend maintaining a target HCT of $21 \%-24 \%$. Hébert et al showed that restrictive transfusion and liberal transfusions were of equivalent value in critically ill patients, while relatively stable patients undergoing liberal transfusions had a higher 30-day mortality.[10] The conclusive consensus form various protocols and guidelines suggest that the transfusion is rarely indicated in $\mathrm{Hb}>10 \mathrm{~g} / \mathrm{dL}$. If $\mathrm{Hb}$ is $<6$ $\mathrm{g} / \mathrm{dL}$ transfusion is indicated irrespective of cause and condition of the patient. If $\mathrm{Hb}$ is between 6 and $10 \mathrm{~g} / \mathrm{dL}$, the indication will depend upon whether patient is actively bleeding or having history of previous haemorrhage or having some medical condition where optimal $\mathrm{Hb}$ of $>7 \mathrm{~g} / \mathrm{dL}$ is required.[11] The common goals for transfusion in the obstetric patient ${ }^{[12]}$ is to achieve-

- Haemoglobin $>8 \mathrm{~g} / \mathrm{dL}$,

- Platelet count $>75 \times 109 / \mathrm{L}$,

- Prothrombin time (PT) $<1.5 \times$ mean control,

- Activated PT $<1.5 \times$ mean control, and

- Fibrinogen $>1.0 \mathrm{~g} / \mathrm{L}$.

Patients receiving less than 10 units of RBC's rarely need component replacement. The lowest mortality occurs in patients where ratio of plasma: RBC's is $1: 1$. Both the CMQCC Toolkit and the RCOG Green top Guideline No. 52 recommend a ratio of $\mathrm{PRBC}$, fresh frozen plasma and Platelet of 6: 4:1 in cases of massive haemorrhage.[13,12]

Recombinant factor VII is an expensive therapy that may be considered in obstetric haemorrhage. It is primarily used as a treatment of uncontrolled haemorrhage in trauma setting. It causes a thrombin burst and promoting clotting in open vessels. Its effectiveness is markedly diminished by hypothermia and acidosis. So, effective resuscitation towards normal physiology is a prerequisite of its use. It is given in a dose of $90 \mu \mathrm{gm} / \mathrm{kg}$. It had thrombotic complications.

Intraoperative cell salvage is a technique in which patient's own blood cells are re-transfused after separation from lost blood.[14] IBS has been used in both anticipated and unanticipated massive haemorrhages like ectopic pregnancies, ${ }^{[15]}$ caesarean sections, in vaginal deliveries and is acceptable under certain circumstances to Jehovah's witnesses.[16] The risk of IBS is embolism and alloimmunisation. To reduce this risk cell salvage is usually started after the majority of the amniotic fluid has been suctioned. A leucocyte depletion filter should be used prior to reinfusion of the salvaged blood to remove additional contaminants that the washing process may not clear. Cell salvaged blood contains only red blood cells with no clotting factors and platelets.
Antifibrinolytics help in reduction of blood loss during obstetric surgeries and other haemorrhages. Tranexamic acid is a potentially useful drug, which is widely available. It can decrease bleeding and reduce the need for further transfusion without many major side effects. The initial dose is a slow intravenous infusion of 1 gram followed by a further 1 gram four hours later. Some studies have shown that tranexamic acid reduces the postpartum haemorrhage.[17]

The other conservative treatment is administration of uterotonic drugs. The commonly used uterotonic drugs are oxytocin, methylergometrine, prostaglandin F $2 \alpha$ (carboprost) and prostaglandin E1 analogue (misoprostol).

Oxytocin causes vasodilation and is harmful in the haemodynamically unstable patient. It is given slowly in the infusion at a rate of $10 \mathrm{IU} /$ hour for four hours.

Ergometrine is given in a dose of $400 \mu \mathrm{gm}$, either slow intravenous route or intramuscular. It causes nausea, vomiting and may precipitate hypertension. So it should be avoided in pregnancy-induced hypertension and heart disease complicating pregnancy.

Prostaglandin F2 $\alpha$ (carboprost) is given in a dose of 0.25 $\mathrm{mg}$ intramuscularly and repeated upto $2 \mathrm{mg}$. Intramyometrial administration has a more rapid onset. Side effects are hypertension, pulmonary hypertension and bronchospasm. It should be avoided in bronchial asthma patients.

Misoprostol is useful in combination with other uterotonic agents. It can be used rectally, orally or sublingually. The recommended dose is $800 \mu \mathrm{gm}$.

After controlling the acute situation, care should be given to avoid the occurrence of rebound hypercoagulation and the risk of thromboembolism. Pregnant women are physiologically hypercoagulable and those who have received blood products have a further increase in the incidence of thromboembolic disease. To avoid this, thromboprophylaxis should be given and compression stockings should be worn.

\section{CONCLUSION}

Obstetric haemorrhage is the commonest cause of maternal mortality. Early resuscitation with simultaneous detection of the cause and treatment is more important. Improved obstetric care, timely intervention and ready availability of blood and blood products may reduce the maternal mortality. In our hospital from our study out of 250 obstetric haemorrhage patients, 18 patients died of DIC, Sepsis, ARF and ARDS. Out of this, DIC is the commonest cause of mortality. Four patients were referred for dialysis. 228 patients were discharged with good general condition.

\section{REFERENCES}

[1] Kloster B, Gorlin J. Obstetric hemorrhage. Blood bulletin. $1^{\text {th }}$ edn. St. NW, Washington: Publication Committee Chair 2012.

[2] Rock JA, Thomson JD. Combined compartment defects. Te Linde's operative gynecology. $8^{\text {th }}$ edn. Philadelphia: Lippincott- Raven 1997:245-61.

[3] Nyasulu DN. Haemorrhage in pregnancy. In: De Kock J, Van der Walt C, (eds). Maternal and newborn care. Landsdowne: Juta 2004:21-2,-21-1.

[4] Barber A, Shires GT. Shock. In: Schwartz SI, (edr). Principles of surgery. $7^{\text {th }}$ edn. McGraw-Hill 1999:10122. 
[5] Magann EF, Evans S, Chauhan SP, et al. The length of the third stage of labor and the risk of postpartum hemorrhage. Obstet Gynecol 2005;105(2):290-3.

[6] Morton PG, Fonteine DK, Hudak CM, et al. Critical care nursing: a holistic approach. $8^{\text {th }}$ edn. Philadelphia: Lippincott Williams \& Wilkins 2005.

[7] Shields L, Lee R, Druzin M, et al. Blood product replacement: obstetric haemorrhage. CMQCC obstetric haemorrhage toolkit, obstetric haemorrhage care guidelines and compendium of best practices reviewed by CADPH-MCAH: $2014 . \quad$ Available from:http://www.mail.ny.acog.org/website/Optimizi ng_Haemorrhage/Transfusion_Policy.pdf.

[8] Arulkumaran S, Mavrides E, Penney GC. Aberdeen prevention and management of post-partum haemorrhage. RCOG green-top guideline 52. 2009. Available from: http://www.rcog.org.uk/womenshealth/clinical-guidance/prevention-and-

management-postpartum-haemorrhage-green-top-52.

[9] Hébert PC, Wells G, Blajchman MA, et al. A multicenter, randomized, controlled clinical trial of transfusion requirements in critical care. Transfusion requirements in critical care investigators, Canadian critical care trials group. $\mathrm{N}$ Engl J Med 1999;340(6):409-17.
[10] Ashworth A, Klein AA. Cell salvage as part of a blood conservation strategy in anaesthesia. $\mathrm{Br} \mathrm{J}$ Anaesth 2010;105(4):401-16.

[11] Allam J, Cox M, Yentis SM. Cell salvage in obstetrics. Int J Obstet Anesth 2008;17(1):37-45.

[12] Weiskopf RB. Erythrocyte salvage during cesarean section. Anesthesiology 2000;92(6):1519-22.

[13] Liumbruno GM, Liumbruno C, Rafanelli D. Autologous blood in obstetrics: where are we going now? Blood Transfus 2012;10(2):125-47.

[14] Novikova N, Hofmeyr GJ. Tranexamic acid for preventing postpartum haemorrhage. Cochrane Database Syst Rev 2010;7:CD007872.

[15] Shander A, Gross I, Hill S, et al. A new perspective on best transfusion practices. Blood Transfus 2013;11(2):193-202.

[16] Falk JL, O'Brein JF, Kerr R. Fluid resuscitation in traumatic hemorrhagic shock. Crit care clin 1992;8(2):323-40.

[17] The American college of surgeons shock. In: The American college of surgeons, (edr). Advanced trauma life support 1990:59-73. 